\title{
Practice of Social Responsibility in Moroccan Companies « An Exploratory Study»
}

\author{
Mouna El Mousadik (PhD student) \\ Fatima El Kandoussi (PhD)
}

National School of Business and Management, Larefa, Agadir, Morocco

Doi: 10.19044/esj.2017.v13n31p127 URL:http://dx.doi.org/10.19044/esj.2017.v13n31p127

\begin{abstract}
This paper discusses the concept of Corporate Social Responsibility in the Moroccan context. The main purpose of this study is to draw up an inventory current situation of the CSR in Moroccan small business companies, as such to help understand the commitment of this type of business in sustainable economic development.

It has been proven, by the survey among forty small Casablanca business leaders representing different sectors of activity, that the managers integrate unknowingly in their management the concept of SR, and that when it comes to social practices a link certainly exist between the company and its stakeholders (costumers, providers...).

The survey shows that more than half of the interviewed executives stipulate that either they heard or know about SR; this awareness towards the concept is an increasing function which depend on the size of company. As also Moroccan leaders are aware of the advantages in engaging social responsibility approach in their business; this finding suggests as well that social responsibility can be of direct economic value for the firm.
\end{abstract}

\section{Keywords:}

\section{Introduction}

At the present time new aspirations have emerged regarding people's perceptions towards "Green" concepts such as life quality, environment protection and sustainable development. Performance is no longer limited to the financial dimension of doing business. Indeed, the survival of companies depend on the behavior and the responsibility of firms towards their stakeholders (shareholders, associations, NGOs, unions, customers, suppliers...).

For over a decade, Corporate Social Responsibility (CSR) has become notably important regarding companies' practices and worldwide 
discourses. The World Bank (2004) defines corporate social responsibility (CSR) as "the commitment for the business towards the community to contribute to sustainable economic development, working along with employees, their families, the local community and society at its large term in order to improve the quality of life in great manners for both the local development and for the business. »

A large number of discussions and researches regarding CSR tend to ignore curiously the concept of SMEs in their approach. Given the importance and the role of SME s in the economic development of countries, it is almost certain that understanding the philosophy provided by a CSR culture would generate an added value and undoubtedly progress and an improvement of both companies ' social and economic performance. The SMEs has to be considered as a socio-economic actor which can do well but also do much harm, consequently SMEs should urgently involve "civil society" as far as different types of actors and protagonists in its environment within its strategy and managerial logic (Alberto \& Combemale, 2010).

Moroccan companies are facing a new era associated with the development of its activities. The globalization of the economy lay down an order marked by an open market in which business competitiveness is reached through innovation (both technological and organizational) as a key comparative advantage over other economies with lower labor force costs. Accordingly, opportunities and constraints for integrating social responsibility (CSR) in Morocco are diverse.

This paper tends to illuminate CSR practices in Morocco and especially in the SMEs. The purpose of this study is to measure the degree of awareness of this type of business to the importance of CSR and measure their current managerial practices regarding aspects of social responsibility.

This stream of information leads us to ask the following question:

\section{What is the level of awareness and integration of socially responsible practices in Moroccan small and medium size companies?}

To answer these questions, a survey has been conducted among forty different sectors Moroccan SMEs. Throughout this paper, the SMEs vision towards the concept of CSR will be outlined, then a framework about the circumstances of CSR in Morocco will be presented as well. Finally, the field of study will be summarized, along with the research methodology and the results.

\section{Theoretical links between SME and CSR}

Traditionally the concept of CSR attracts and interests only large firms, as SMEs does not have enough resources in order to maintain a socially responsible approach while doing business (Lepoutre and Heene, 
2006). However, the report of the European Commission (EC, 2002) showed that CSR programs have a positive impact on companies' management and competitiveness, as well as CSR promotion strategy is fundamentally based on a set of principles with "taking into account the specific needs and requirements of SMEs' (EC, 2002).

The ability of a CSR approach in reinforcing and supporting the values of any company through its "Defensive, reactive and interactive" characteristics (Ackerman, 1973) is totally significant. It is crucial for a company to build its own CSR strategy from its own fundamental values. Otherwise, it would be "condemned to failure if CSR is paradoxical and conflicting with its core principles and values" (Hilby, Sabatier, 2012). Moreover, it is not to add the three concepts of CSR, already mentioned, to the core activities of companies. CSR must be a component and directly integrated within the company management (EC, 2002), supposed to be integrated into a larger whole, which is that of society (Hayek, 1993). A challenge to defeat since social feedback depend undoubtedly on "the company's ability to respond to social pressure" (Frederick, 1978).

Social responsibility is rarely studied in SMEs (Paradas, 2007) and certainly there are many obstacles facing its integration in SMEs, among these contingency factors we distinguish: the size and turnover, the influence of the owner-managers and their strategy, the centralized organization, the low specialization and simple or informal information systems (Delchet, 2007).

Accordingly, the importance of the owner-managers' influence has to be outlined and mentioned as it goes to the SMEs managers to apply and maintain the content of CSR(Piore and Sabel, 1984) and would be obliged to do so in order "to try to show a positive humanist image of the company towards its stakeholders" (Delhaye and Cornet, 2004), in an oriented environment nowadays towards concepts such as "social economy", ensuring the alliance between the "economic viability and social responsibility" (EC, 2002).

A research conviction emphasizes only and mainly on large companies. The context of research regarding SMEs CSR is often related to the management of CSR in the supply chain of large firms, and rarely for itself as a concept. The term of SME (PME in French) is, in the most cases, missing within the existing CSR theory approaches and models, a clear fact just by checking the index of books dedicated to draw up an inventory of CSR $^{1}$.

${ }^{1}$ See for example Caroll, A.B. \& Buchholtz, A.K., (2006) Business and society: Ethics and Stakeholder Management, Thomson South Western ; Crane, A., Mc Williams, A., Matten, D., Moon, J., Siegel, D. (2008), The Oxford Handbook of Corporate Social Responsibility, Oxford University Press. 


\section{Corporate Social Responsability: Practices in the national context}

The European Commission provides a simple definition of social responsibility: "Corporate responsibility for their impacts on society." Corporate social responsibility is a management concept that refers to activities through which companies decide to integrate social and environmental concerns in their business operations and manage their stakeholders (employees, customers, suppliers, shareholders, etc.). The concept of CSR designates a company's logic of responsibility towards the economic, social and ecological environment in which it operates. Companies are to be supposed " socially responsible" when they assume the entire responsibility for their impact on society.

\section{The levers of CSR in Morocco}

CSR was introduced in Morocco by the multinational companies that are engaged in such processes and by their local partners (Filali Maknassi, 2009). Its development is due to a positive global context that comes with legal and institutional reforms, such as the National Human Development Initiative (INDH), reform of the legislative framework and the standardization movement.

Initiated by King Mohammed VI in May 2005, The National Initiative for Human Development aims to develop the foundations of a national program for the integration of social objectives in investment decisions. In this context, the royal speech is a strong and positive political signal and a vector incentive and encouragement to private initiatives: " investors social responsibility has while and for condition corporate social responsibility requirement. In this regard, we follow with interest and appreciation the actions and the efforts of Moroccan companies who have voluntarily engaged in this way "(From the Message of his highness the King Mohammed VI in the third edition of "Intégrales de l'Investissement », 2005). Concretely, the king initiative offers to the economic actors a reference framework and financial resources $(25$ million Euros for its first five first year social for the promising ${ }^{2}$ economic context in order to maintain and boost a dynamism.

Morocco is living a full emergent normalization movement and the year 2004 marks the debut of a new Moroccan labor code which reinforces the local legislative framework to the attachment to human rights and international labor conventions, giving place for mediation proceedings authorities, arbitration, consultation and mechanisms for periodic collective negotiations. The new Labor Code provides adaptive instruments for certain measures to sectoral and organizational characteristics, mostly internal tools

\footnotetext{
${ }^{2}$ http://www.indh.gov.ma/fr/programme_2005
} 
such as the work council, the health and safety committee, the company agreement and branch collective agreement...

The Ministry of Industry, Trade and the promotion of the economy shows great market demand regarding this field. Several Moroccan standards related to the management of social aspects in the company, were founded particularly through the NM00.5.600 standard (Management system of social aspects). This standard refers to the principles defined in the SA 8000 (Social Accountability 8000) and eleven conventions of the international Labour Organisation. It is compatible with other management systems (quality, environment and safety) and aims to standardize local regulations and labor code. The standard also provides general guidelines for establishing and managing a social audit system.

\section{Forms of CSR Practices in the Moroccan context}

Industrialization is the main feature of the Moroccan CSR. Its development is supported by a considerable amount of institutional incentives and normative measurements and benchmarking, CSR knows true industrialization, its rise and its dissemination is facilitated also by the development of institutional and normative levers and measurement and benchmarking process through the development of social and extra-financial assessments, standards and labels.

In this context and without including a structured and coordinated approach, the government within the Moroccan companies, for 20 years, are preparing to deal with these trends, $\mathrm{b}$ asically by raising numerous organizational programs as well as human resources and technologies as they are well implemented in order to offer the best possible offshore conditions for foreign direct investment and similarly to promote exportations to external markets for several sectors companies.

It has been 20 years now, since the implementation, for the Moroccan companies, of different management practices by choice and constraint necessity. These improvement and implementation practices have not failed to shape corporate management methods. Among these practices, the management systems based on international standards, implemented in more than 1,000 Moroccan companies need to be mention. Regarding the same context described above and since the year 2006 (date of adoption of social responsibility charter "CGEM"), new practices have emerged as well.

It is around sixty companies, both small and medium sized, are

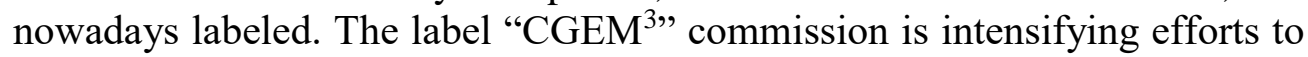
adhere new companies. Additionally, it is clear that these labializations are

\footnotetext{
${ }^{3}$ The General Confederation of Enterprises of Morocco
} 
still limited to large companies and subsidiaries of multinationals firms. Although several managers of SMEs manifest their engagement and readiness in this way and confirm that the CSR, beyond ethical considerations, brings opportunities for managerial innovation and sustain for the companies, relations with its environment.

\section{Empirical study: Drawing up the situation of CSR in Moroccan SMEs Study Methodology}

The overall purpose of this study is to come with an inventory of the CSR awareness concept by Moroccan SMEs (managers, owners, entrepreneurs etc). The study is entirely exploratory, designed to highlight the opinions and perceptions of managers about the concept.

This survey is adopted from the study of M'Hamdi and Trid (2009), Adaskou (2011) in the case of SMEs. The choice of these studies as a reference is justified by the aim to make an advanced research on CSR in SMEs located in the city of "Casablanca". The questionnaire was the main instument chosen to collect information from SMEs within the target region.

The questionnaire takes into consideration the theoretical framework outlined above. It includes the following topics:

- Identify the features of the target firms;

- $\quad$ Focus on the perception degree and awareness of CSR by business owners;

- $\quad$ Study the CSR practice obstacles,

- $\quad$ Emphasize on the social and societal as well as the environmental aspects of CSR.

The quantitative study has been conducted among SMEs, all sectors included during the month of February 2016. Furthermore, it was essential to establish a set of criteria to draw up an inventory of CSR situation only among the target companies. Therefore, the results cannot be extended to the rest of Moroccan companies. In this sense, a survey was conducted among 40 business SMEs within Casablanca city region where most companies of the country are concentrated ${ }^{4}$. In order to look for and represent entrepreneur's perception to the concept of CSR, for this aim, the statistical software Sphinx V5 was used for the factorial correspondence and data analyses.

It should be mentioned that companies subject of survey have been selected only among SMEs. Regarding the date of their creation, $71 \%$ exist on the market since the early 90 s and their staff varies between 100 and 150 employees, while the rest was created 8 years ago and recruit between 40 and 120 people.

\footnotetext{
${ }^{4}$ www.hcp.ma/file/103294/
} 
Most of the concerned companies of this survey are installed in industrial zones (Ain Sebaa and Mohammedia). Three main sectors are presented among the target companies:

- $50 \%$ represents industrial sector,

- $\quad 30 \%$ are among those of service,

- $\quad 17.55 \%$ are agricultural SMEs.

- $2.45 \%$

\section{Study results: SMEs Perception of CSR}

The Survey among Moroccan entrepreneurs shows that $70 \%$ of companies' leaders are already familiar with the concept of CSR, representing the following sectors:

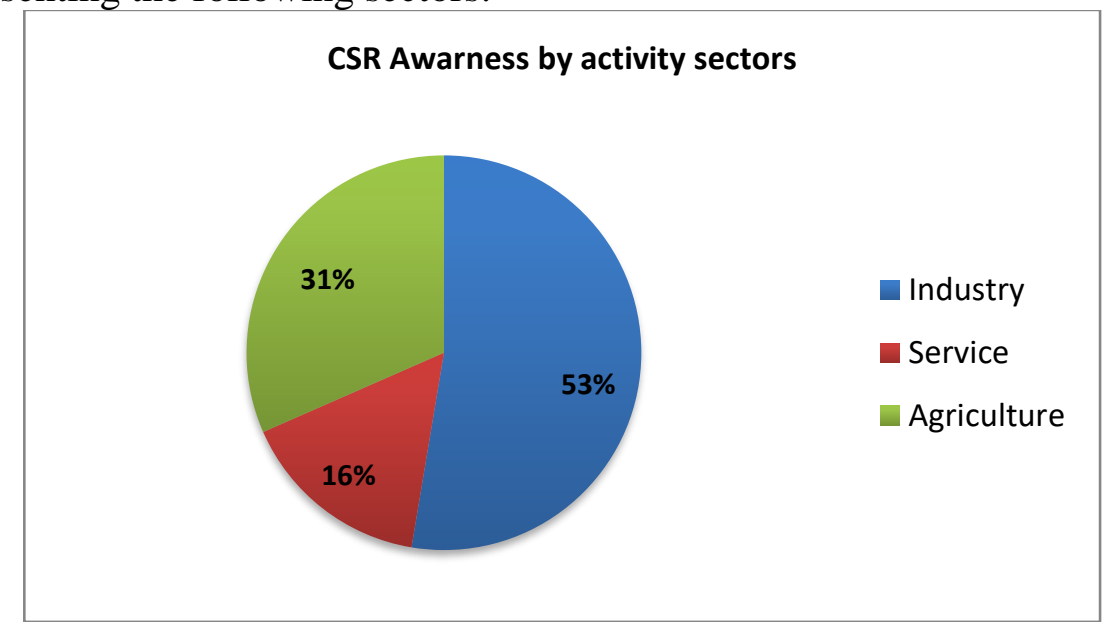

Response rates are much negative in terms of knowledge received among companies' managers regarding institutions offering help applying CSR initiatives (55\% of companies answered they do not know about it).

The same results were found regarding the implementation of CSR initiatives by "knowledge repositories" (60\% of the examined companies are not informed about it). Almost 35\% of companies consider CSR as a major asset. Others think about it as a minor asset or constraint.

Various advantages of CSR function in companies can be mentioned such as: consumers and customers' loyalty $87.7 \%$, important relationships with suppliers $72 \%$ and good relations with the local environment.

\section{$>\quad$ Limits of CSR practices:}

Surveyed managers consider the size of their business as been too small to engage a CSR strategy within their companies $(34 \%$ of respondents), while $28 \%$ estimate their financial situation as insufficient to 
consider social responsibility. Moreover, clients of $60 \%$ of the investigated SMEs are not really expecting a CSR as a strategy of their company.

According to the survey, the companies' clients can be source of influence regarding the decision of implementation or not of SR. In addition, and regardless of the company's size and activity, managers' reservations towards SR concept are always similar.

\section{$>\quad$ The practice of CSR (The Willingness to practice CSR)}

About $45 \%$ of the interviewers are willing to seriously consider a responsible measure of purchasing process in their business in the upcoming years.

\section{$>\quad$ CSR related to social issues:}

Almost $80 \%$ of the interviewed SMEs sample demonstrates a considerable respect of freedom of worker's associations and about 100\% reinforce equalities between employees.

As regards, companies are aware and responsible of the importance of working conditions factor and assume its significant value and interest.

Employees rule in the development of their working place is important, a fact confirmed by $45 \%$ of the surveyed companies. Consequently, companies engage several means to gain their fidelity and commitment: asking their employees about their career aims, recompense and their appreciation of different processes within the company.

These implements and mechanisms allow to assure a closer view and better understanding of the employees and help prepare plans and career opportunities within the company and guarantee balance between employees private and professional life. Enhancing working conditions are also taken into consideration by the majority of SMEs (62\%), promoting employee's life quality in the organization by improving the environment and the work living climate.

In general, managers implement a comfortable work place by establishing resting rooms and common spots but also prayer area and other facilities. Moreover, adopting flexible work calendar seem to be a great way of improving the quality of working conditions, as well as organizing sport events and competitions help reducing employees distress.

\section{$>\quad$ CSR environmental issues:}

The majority of the surveyed companies are industrial, which leaves us to ask questions about achievement efforts regarding environmental protection initiatives (reducing pollution, recycling, new production methods...). 
A major number of Firms in the chosen model, have no certification (among them $82 \%$ are very small size, $93 \%$ small and 86 are from medium size). Several types of certifications such as ISO 9001, ISO 26000, and ISO 14001 are noticed to be among those currently used by these companies. The lack of certification is due to company's customers and suppliers which never show a demand or requirement regarding the certification process.

Considerable number of companies surveyed does not adopt a recycling technique. In addition, nearly all of the companies surveyed are making use of energy saving plans, including industrial companies, for example by using energy-saving lamps, which is one of the actions included among a list of sustainable development practices. While manufacturing and commercial companies confirm making environmental protection choices regarding their energy and raw materials purchase.

\section{Societal issues and CSR in Morocco}

The societal aspect of CSR concern companies' relationship with its suppliers and customers, but also with other components of civil society (administrations, associations, other companies ...). According to the surveyed managers given responses, SMEs, with a SR orientation, asked some of their suppliers to commit to certain formalities and conditions related to the survey subject.

Investing in SR, requires offering advice from the company to its clients especially regarding the influence of their purchasing choices on the environment and their welfare. It has to be mentioned that three out of nine of the surveyed companies receive requests among their clients to respect SR conditions.

\section{Conclusion}

Clearly a number of SMEs ignore their CSR practices within their business activities. Certainly SME's owners do not necessarily have an interest regarding this subject and their efforts are not formal because they cannot afford the services of a professional CSR expert. Although a CSR approach seems to be a key factor in order to unlock doors for new opportunities such as innovation, risk management and financial statements improvement.

Yet a surprising number of both small and medium size companies are nowadays interested or engaged in a CSR approach, others are actually still considering the fact that engaging CSR among their operational activities is a substantial key asset. However, and beyond that fact, most significant results on that field is still the outcome of large companies

One of the major difficulties of SMEs regarding the SR, compared to larger companies, is related to some standards and laws, for example ISO 
26000, supposed to be a standard that provides a useful framework and intended to fit with SMEs specificity, is now the large companies' principal requirement.

The progress of CSR may be one of the major entrepreneurial changes in the upcoming years, for this reason and under certain specificities, leaders undoubtedly will be increasingly in required to reconsider their affairs' social values and dimensions in order to be part of a possible new management future order.

\section{References:}

1. Ackerman, R. W. (1973). How companies respond to social demands". Harvard Business review, 51 (4): 88-98.

2. Alberto, T., \& Combemale, P. (2010). Comprendre l'entreprise: théorie, gestion, relations sociales. A. Colin.

3. Benabou D. et Bendiabdellah D.J. (2009). Perception des dirigeants de PME de leur responsabilité sociale: une approche par la cartographie cognitive, La Revue de l'Economie et de management, 9, $15 \mathrm{p}$.

4. Caroll, A.B. \& Buchholtz, A.K., (2006). Business and society: Ethics and Stakeholder Management, Thomson South Western;

5. Crane, A., Mc Williams, A., Matten, D., Moon, J., Siegel, D. (2008). The Oxford Handbook of Corporate Social Responsibility, Oxford University Press.

6. Delchet-Cochet, K. (Juin 2007). Développement durable. L'intégrer pour réussir. Thèse de doctorat. Editions AFNOR.

7. Delhaye, C. et Cornet, A. (2004). Arguments managériaux pour une responsabilité sociale des entreprises : le cas de la gestion de la diversité de la main d'œuvre. Actes du congrès IAS, Luxembourg.

8. Filali Maknassi, R. (2009). Quel avenir pour la responsabilité sociale au Maroc? IDroits de 1'Homme et développement durable: quelle articulation.

9. Frederick, W. C. (1994). From CSR1 to CSR2: The maturing of business-and-society thought". Business and Society. London: Sage, 33 (2): 150-166.

10. Hayek, F. A. (1993). La présomption fatale : Les erreurs du socialisme. Traduit de l'anglais par Raoul Audouin et révisé par Guy Millière. Paris: PUF. (Collection Libre échange),237p.

11. Léopold, D et al. (2014). La responsabilité sociale d'entreprise dans les P.M.E. africaines : bilan, enjeux et perspectives, Revue Congolaise de Gestion (Numéro 19), p. 113-141. 
12. Lepoutre, J. et Heene, A. (2006). Investigating the Impact of Firm Size on Small Business Social Responsibility: A Critical Review. Journal of Business Ethics, 67 (3): 257-273.

13. Mireille, C. (2015). Pratiques de RSE sociale dans les PME libanaises : une prise de conscience, Question(s) de management $\left(\mathrm{n}^{\circ}\right.$ 9), p. 37-51.

14. M'HAMDI. M, (2009). La responsabilité sociale de l'entreprise au Maroc: une étude empirique auprès des petites et moyennes entreprises de la région de Fès Boulomane 11ème Journées scientifiques du Réseau Entrepreneuriat, 27, 28 et 29 mai 2009, INRPME, Trois-Rivières, Canada

15. Paradas, A. (2007). Le dirigeant comme levier de la RSE en TPE. Approche exploratoire basée sur l'utilisation de récits et d'une cartographie cognitive », Revue Internationale PME, Numéro spécial : «Les PME et la responsabilité sociale des entreprises », 20 (3-4) : 43-67.

16. Piore, M. et Sabel, C. (1984). The Second Industrial Divide. New York: Basic Books.368p.

17. Sabatier, M. et Hilby, S. (2012). Responsabilité sociale et environnementale de l'entreprise: 5 bonnes pratiques, le cercle. Les échos.fr. Repéré à : http/ archives.lesechos.fr/archives/.../07/.../ cercle_49945.ht...

18. Sandrine Berger-Douce (2012). Chapitre 3 : Les enjeux stratégiques de la RSE pour la PME, in JeanMarie Courrent, RSE et développement durable en PME, De Boeck Supérieur "Petites Entreprises \& Entrepreneuriat », p. 51-61.

\section{Websites :}

19. www.hcp.ma/file/103294

20. http://www.cgem.ma/ 